\title{
Religious Experience and the Probability of Theism: Comments on Swinburne
}

\section{CHRISTOPH JÄGER}

Religious Studies 53 (2017), Special Issue 3: In Honour of Richard Swinburne, pp. 353-370

\section{Introduction}

Throughout the centuries religious experience has been a bedrock of religious faith. Analysing its epistemological role is thus a central task for the philosophy of religion. Here I discuss Richard Swinburne's account of religious experience as he lays it out in his modern classic The Existence of God. Swinburne's work in the philosophy of religion, as well as in other areas of philosophy, is enormous - not only in terms of philosophical depth and methodological rigour, but also in terms of originality and scope. ('Some of us write a lot', I remember him once saying, 'and some of us write even more than that.' He made this latter remark, characteristically, not about himself but about another philosopher.) I am slightly disheartened to have to line up against such a philosophical giant. ${ }^{1}$ Yet I shall argue that there are problems with Swinburne's account of religious experience and thus some outstanding issues that his overall probabilistic case for theism needs to untangle.

Swinburne construes theism as a large-scale hypothesis about the origin and features of the universe. Theism is the view that there is a God who has created that universe and who, on Swinburne's account, also has (more or less) the other traditional characteristics ascribed to him by the great theistic traditions of Judaism, Christianity, and Islam. Swinburne argues that the universe and many of its features are better explained by theism than by any rival hypothesis, including any purely naturalistic explanation of the universe. Indeed, he maintains that there are no purely naturalistic ultimate explanations of the universe and hence that the naturalist is bereft of any ultimate explanation for it. Moreover, religious experience is an important datum that an ultimate explanation must account for, and as such it plays a significant evidential role in Swinburne's overall case for theism.

Swinburne formulates his account of the evidential force of religious experience in terms of Bayesian confirmation theory. His first step is to argue that each available piece of evidence - putting aside religious experience for the moment - raises the probability of theism to some degree, and that the problem of evil does not decisively lower it. In a second step he argues that evidence from religious experience tilts the balance in favour of theism: If 
we consider religious experience apparently of God in addition to all the other evidence, theism comes out as more probable than not.

Some might have reservations about treating theism as a quasi-scientific hypothesis. Others might be unhappy about applying Bayesianism in this context; or they might reject Bayesian confirmation theory as a model for rational belief in general. Moreover, even if one accepts Bayesianism there may be problems with assigning an intrinsic probability to a proposition such as 'God exists'. But I will not question these aspects of Swinburne's general picture; instead I will meet him on his own ground. I will take his probabilistic approach seriously, but present two problems, or challenges for it. One was initially formulated by Winfried Löffler (1999, 2007), who argues that, given Swinburne's setup, the conditional probability of theism rapidly converges towards 1 . So much the better for theism, some of us may happily respond. Yet, if this objection is sound, it will plausibly constitute a reductio of Swinburne's argument. That the probability of theism is almost 1 seems too good to be true.

My second argument is inspired by an influential Bayesian objection to so-called dogmatism about perceptual justification. Here 'dogmatism' is not meant to carry any pejorative connotations. Rather, it refers to the anti-sceptical idea that when it perceptually seems to you as if $p$, then you are thereby prima facie justified in believing that $p^{2}$; seemings or appearances, so the idea runs, can provide (defeasible) immediate justification for the corresponding beliefs and can justify agents in holding those beliefs without antecedent justification for rejecting sceptical alternatives. Perhaps the most influential version of the Bayesian objection to dogmatism has been presented by Roger White (2006). White concludes that your posterior probability for the belief that $p$, given that it perceptually seems to you that $p$, cannot exceed your prior probability for the negation of sceptical competitors to $p$. Likewise, it seems, your epistemic justification for believing that $\mathrm{p}$ cannot exceed your justification for believing that a sceptical alternative to $p$ is false. For example, your rational credence in (and justification for) the proposition that you have hands, updated in the light of an experience as of hands, cannot exceed your prior credence in (and justification for) the proposition that you are not a handless brain in a vat having an experience as of hands. Or so the argument goes. (For helpful recent discussions see, e. g., Brogard (2013), Pryor (2013), Tucker (2013b), Moretti (2015a, 2015b), Miller (2016); and the literature quoted in section 4). I argue that an analogous observation applies to religious seemings as discussed by Swinburne. If they provide additional justification for religious beliefs, they should also provide additional, new justification for disbelieving alternative, incompatible, explanations 
for their occurrence. However, the Bayesian argument shows that they cannot provide such justification.

In the next section I reconstruct Swinburne's argument about the role of religious experience. The third section discusses the convergence problem; I then develop the Bayesian objection against Swinburne just outlined. However, in the final section I conclude that the question whether theism is more probable than not is less important than it may initially appear to the reader of The Existence of God (EG; I shall abbreviate the first and the second editions with ' $E G^{1}$ ' and ' $E G^{2}$ ', respectively). The crucial issue, I suggest - as does Swinburne himself in Faith and Reason - is the rationality of faith. But arguably the latter does not require rational belief that the probability of theism exceeds 0.5 .

\section{Religious Experience in Swinburne's Argument for Theism}

Swinburne lays out his core argument in terms of Bayesian confirmation theory. According to the latter, a piece of evidence $e$ confirms a hypothesis $h$ iff $e$ increases $h$ 's prior probability. Swinburne distinguishes two cases. A ' $\mathrm{C}$-inductive argument' is an argument to the effect that $e$ makes $h$ more probable than $h$ was before $e$ was considered. A 'P-inductive argument' is one according to which $e$ makes $h$ more probable than not; that is, a P-inductive argument raises $h$ 's probability beyond $50 \%$. Swinburne's ultimate aim in EG is to present a good Pinductive argument for theism $\left(\mathrm{EG}^{2}, 329\right)$, and he thinks this can be done. His account relies on the evidence from religious experience.

In the first part of the book Swinburne considers five pieces of evidence - the existence of a physical universe, its orderliness and beauty, the existence of conscious beings, the nature and needs of conscious beings, and the (alleged) occurrence of miracles - and argues that each of them provides a good $\mathrm{C}$-inductive argument for theism. That is, each raises the probability of theism (or 'confirms' it); for each $e, \mathrm{P}(\mathrm{h} \mid \mathrm{e} \& \mathrm{k})>\mathrm{P}(\mathrm{h} \mid \mathrm{k})$. Swinburne also argues that the problem of evil fails to constitute decisive evidence against theism. However, as he concedes, given the comparatively low initial probability of theism, each piece of evidence leaves the posterior probability of theism still very much lower than 0.5 . But this is not the end of the story. First, we should also consider the cumulative force of all the Cinductive arguments. ${ }^{3}$ Second, there is the evidential force of religious experience.

The term 'religious experience' is somewhat fuzzy. For present purposes Swinburne construes it narrowly as 'an experience that seems (epistemically) to the subject to be an experience of God (either of his just being there, or of his saying or bringing about something) 
or of some other supernatural thing. ... For most of the discussion I shall be concerned with experiences that seem to be simply of the presence of God and not with his seeming to tell the subject something specific or to do something specific' (EG ${ }^{2}, 295-296$; cf. EG $\left.{ }^{1}, 246-247\right)$. I shall not question that such experiences - perhaps even frequently - occur.

Another cornerstone of Swinburne's argument is his Principle of Credulity:

\section{The Principle of Credulity (PC)}

'[I]t is a principle of rationality that (in the absence of special considerations) if it seems ... to a subject that $\mathrm{x}$ is present (and has some characteristic), then probably $\mathrm{x}$ is present (and has that characteristic); what one seems to perceive is probably so. ...How things seem to be (in contingent respects) [footnote omitted], that is how we seem to perceive them, experience them, or remember them are good grounds for a belief about how things are or were' $\left(\mathrm{EG}^{2}, 303\right.$; $\left.\mathrm{cf}^{\mathrm{E}} \mathrm{EG}^{1}, 254\right)$.

'Things are probably so as they seem to be' $(1999,142)$.

PC is by no means idiosyncratic. Many other epistemologists, including many who apparently have no inclinations to use such views to support theism, have postulated similar principles. For example, James Pryor argues that:

'[W]henever you have an experience as of $p$ 's being the case, you thereby have immediate (prima facie) justification for believing $p$.... For a large class of propositions, like the proposition that there are hands, it's intuitively very natural to think that having an experience as of that proposition justifies one in believing that proposition to be true' (Pryor (2000), 532, 536).

Pryor famously calls this position 'dogmatism' (about perceptual justification). Similarly, in Skepticism and the Veil of Perception, Michael Huemer defends a 'principle of phenomenal conservatism':

'If it seems to $S$ as if $P$, then $S$ has at least prima facie justification for believing that $P^{\prime}$ (Huemer (2001), 99).

Such principles are close cousins of Swinburne's Principle of Credulity. Dogmatism is a view about perceptual justification; phenomenal conservatism says that seemings more generally - 
perceptual or otherwise - provide prima facie justification for the corresponding beliefs. (So, dogmatism is phenomenal conservatism restricted to perception. ${ }^{4}$ ) Although Swinburne often illustrates PC with examples of perceptual experience, the principle is not limited to perception; he also applies it, for example, to apparent memory, introspection, and other kinds of awareness. His position is thus a version of phenomenal conservatism. Now, if PC is correct, Swinburne argues, then - special considerations aside - religious experiences 'ought to be taken by their subjects as genuine, and hence as substantial grounds for belief in the existence of their apparent object - God, or Mary, or Ultimate Reality, or Poseidon' (EG ${ }^{2}$, 304). Swinburne then considers a number of potential reasons for limiting the application of $\mathrm{PC}$ and in particular for not applying it to religious experience, but finds them all wanting.

In addition to PC, he introduces the Principle of Testimony. It says that, absent special considerations:

The Principle of Testimony (PT)

'The experiences of others are (probably) as they report them' $\left(\mathrm{EG}^{2}, 322\right)$.

'We have good grounds to believe what others tell us about their experiences' (EG', 322)

Again, the idea is that we should take other people's testimony about their seemings and experiences as prima facie reliable. Depending on the context, there may be defeaters. In combination, PC and PT yield the claim that, when defeaters are absent, '(with some degree of probability) things are as others report' $\left(\mathrm{EG}^{2}, 323\right)$. Since these principles are not confined to non-religious seemings, this conclusion also applies to people's testimony about having religious experiences as of God. Based on PC and PT Swinburne maintains that we have good reason to believe that there are (and have been throughout the centuries) veridical theistic religious experiences.

Both PC and PT are controversial. But I believe they are plausible and shall not question them here. However, what might those special considerations consist in that would defeat our prima facie entitlement to believe that religious experiences are veridical? According to Swinburne, the only serious defeater would consist in having good reason to believe that the prior probability of theism - which in the context of Swinburne's overall argument is its probability on all the other evidence he considers - is very low. Given PC and $\mathrm{PT}$, he argues, only if on the other evidence 'it is significantly more probable than not that there is no God' (EG ${ }^{2}, 326 ; \mathrm{EG}^{1}, 274$, my emphasis) would the evidence from religious 
experience lose its high evidential value. However, the elaborate $\mathrm{C}$-inductive arguments for theism in the first part of EG are supposed to show that precisely this defeater is lacking. They are not forceful enough to show that theism is more probable than not, according to Swinburne, but their cumulative force shows that it is not very improbable either. The crucial condition for taking religious experiences to yield a good P-inductive argument is thus 'more than adequately satisfied' $\left(E G^{2}, 342\right)$ and hence theism comes out as more probable than not. For the sake of brevity, let us call evidence from religious experience 'experiential evidence'. We may then summarize Swinburne's core argument as follows:

Swinburne's Argument from Religious Experience

A. If the prior probability of theism is not very low given all of the nonexperiential evidence pertaining to it, then the fact that many people have religious experiences apparently of God further raises the probability of theism so that it is more probable than not (i. e., exceeds $50 \%$ ).

B. On the non-experiential evidence, the probability of theism is not very low.

C. Therefore, the evidence of religious experience further raises the probability of theism so that it is more probable than not.

This is an interesting and forceful argument. The dialectic is clear, and the conclusion follows from the premises. There is some vagueness in claims A and B, of course. How low is "not very low'? But I propose granting that we don't need more precision here and that, given the elaborate arguments in the first part of EG, the probability of theism is indeed not 'too close to zero', as Swinburne sometimes says.

The crucial question then is whether premise A is acceptable. Premise A essentially rests on PC and on the view that this principle can properly be applied to religious experience. Several critics have rejected this latter view (for critical discussions see for example Forgie (1986), Martin (1986), Gale (1994), Gutenson (1997)); but here I shall assume that it is tenable. There are two different problems that I wish to discuss.

\section{A Convergence Problem?}

An initial observation is that it is not so easy to come up with plausible probability assignments that would fit with Swinburne's argument. I shall look at an argument to this effect that was initially formulated by Winfried Löffler $(1999,2007)$. As far as I can see 
Swinburne has not responded explicitly to it, although, as we shall see, there are statements in the first and in the second edition of EG (EG ${ }^{2}$ came out in 2004) that are inconsistent with various assumptions in the objection. However, since Swinburne's constraints do not appear in his initial argument, one question is whether he has independent arguments for them or whether they are mere stipulations introduced at a late stage in order to exclude implausible outcomes.

Swinburne employs the apparatus of Bayesian confirmation theory, which obeys the probability calculus. From its axioms, one can derive Bayes's Theorem. ${ }^{5}$ Let $k$ represent tautological background knowledge; $h$ a given hypothesis; and $e$ the relevant evidence. In the present context, $h$ is to be interpreted as standing for theism and $e$ for all the relevant nonexperiential evidence. As Swinburne notes $\left(\mathrm{EG}^{1}, 339\right)$, from Bayes's Theorem we can derive ${ }^{6}$ :

$\mathrm{P}(\mathrm{h} \mid \mathrm{e} \& \mathrm{k})=\frac{\mathrm{P}(\mathrm{h} \mid \mathrm{k}) \mathrm{P}(\mathrm{e} \mid \mathrm{h} \& \mathrm{k})}{\{(\mathrm{P}(\mathrm{h} \mid \mathrm{k}) \mathrm{P}(\mathrm{e} \mid \mathrm{h} \& \mathrm{k})\}+\mathrm{P}(\mathrm{e} \& \sim \mathrm{h} \mid \mathrm{k})}$

In $\mathrm{EG}^{2}$ Swinburne uses a different but equivalent formulation, but for simplicity's sake I shall work with the $\mathrm{EG}^{1}$ version. ${ }^{7}$ The question at this point, then, is how $\mathrm{P}(\mathrm{h} / \mathrm{e} \& \mathrm{k})$ - the probability of theism on all non-experiential evidence (plus background knowledge) - should be assessed. Swinburne argues that consideration of the alternative hypotheses: $\left(h_{1}\right)$ 'There are many gods, or limited gods'; $\left(\mathrm{h}_{2}\right)$ 'There is no God or gods, but an initial (or everlasting) physical state of the universe of such a kind as to bring about the present state of the universe' and $\left(h_{3}\right)$ 'There is no explanation of the universe' $\left(\mathrm{EG}^{2}, 339-340\right)$, reveals that the second addend in the denominator does not exceed $(\mathrm{P}(\mathrm{h} \mid \mathrm{k}) \mathrm{P}(\mathrm{e} \mid \mathrm{h} \& \mathrm{k})$, the numerator, in which case

' $\mathrm{P}(\mathrm{h} \mid \mathrm{e} \& \mathrm{k})$, the posterior probability of theism on the evidence considered so far, will not be less than $1 / 2$. I stress again that it is impossible to give anything like exact numerical values to the probabilities involved in these calculations. I have attempted to bring out the force of my arguments by giving some arbitrary values that do, I hope, capture within the roughest of ranges the kinds of probabilities involved' (EG $\left.{ }^{2}, 341\right)$.

Since the numerator equals the first addend of the denominator, $\mathrm{P}(\mathrm{h} \mid \mathrm{e} \& \mathrm{k})$ equals 0.5 if and only if the numerator and the first addend also equal the second addend, i. e., if and only if $\{\mathrm{P}(\mathrm{h} \mid \mathrm{k}) \times \mathrm{P}(\mathrm{e} \mid \mathrm{h} \& \mathrm{k})\}$ equals $\mathrm{P}(\mathrm{e} \& \sim \mathrm{h} \mid \mathrm{k}) . \mathrm{In}_{\mathrm{EG}}{ }^{1}$ Swinburne concedes that $\mathrm{P}(\mathrm{h} \mid \mathrm{k})$ 'may be low', 
but he maintains that ' $P(e \& \sim h \mid k)$ is very, very much lower' $\left(E G^{1}, 289\right)$. Nothing he says in $\mathrm{EG}^{2}$ suggests that he has given up this assessment. In addition, we now have the constraint that the posterior probability of theism on all the non-experiential evidence will not be less than 0.5. So let us look at some examples that meet the requirements (see table 1). The examples in table 1 neither have a pro-theistic bias nor make $\mathrm{P}(\mathrm{h} \mid \mathrm{k})$ and $\mathrm{P}(\mathrm{e} \mid \mathrm{h} \& \mathrm{k})$ so small as to prevent taking $h$ seriously as a hypothesis (Löffler 1999, 94; 2007, 109). Oops! P(h|e\&k) rapidly converges towards 1 ! The smaller $\mathrm{P}(\mathrm{e} \& \sim \mathrm{h} \mid \mathrm{k})$ is assumed, the greater is $\mathrm{P}(\mathrm{h} \mid \mathrm{e} \& \mathrm{k})$. But of course, the values for $\mathrm{P}(\mathrm{e} \& \sim \mathrm{h} \mid \mathrm{k})$ in rows 3 and 4 of table 1 perfectly accommodate Swinburne's assessment that $\mathrm{P}(\mathrm{e} \& \sim \mathrm{h} \mid \mathrm{k})$ is 'very, very much lower' than $\mathrm{P}(\mathrm{h} \mid \mathrm{k})$.

It may be objected that the prior probability of theism, $(\mathrm{Ph} \mid \mathrm{k})$, which we arbitrarily set at 0.01 , is much too favourable for theism. However, a similar effect occurs if $\mathrm{P}(\mathrm{h} \mid \mathrm{k})$ is lower. For example, with $\mathrm{P}(\mathrm{h} \mid \mathrm{k})=0.0001, \mathrm{P}(\mathrm{e} \mid \mathrm{h} \& \mathrm{k})=0.01$, and $\mathrm{P}(\mathrm{e} \& \sim \mathrm{h} \mid \mathrm{k})=0.000001$, we obtain

\begin{tabular}{|l|l|l|l|}
\hline $\mathrm{P}(\mathrm{h} \mid \mathrm{k})$ & $\mathrm{P}(\mathrm{e} \mid \mathrm{h} \& \mathrm{k})$ & $\mathrm{P}(\mathrm{e} \& \sim \mathrm{h} \mid \mathrm{k})$ & $\mathrm{P}(\mathrm{h} \mid \mathrm{e} \& \mathrm{k})$ \\
\hline 0.01 & 0.01 & 0.0001 & 0.5 \\
\hline 0.01 & 0.01 & 0.00005 & $0.666666 \ldots$ \\
\hline 0.01 & 0.01 & 0.00001 & $0.909090 \ldots$ \\
\hline 0.01 & 0.01 & 0.000001 & $0.990099 \ldots$ \\
\hline
\end{tabular}

table 1

$\mathrm{P}(\mathrm{h} \mid \mathrm{e} \& \mathrm{k})=0.5$; and when we lower $\mathrm{P}(\mathrm{e} \& \sim \mathrm{h} \mid \mathrm{k})$ further to 0.0000001 , we already end up with $\mathrm{P}(\mathrm{h} \mid \mathrm{e} \& \mathrm{k})=0.909090 \ldots$ ! Löffler concludes that Swinburne's account yields a much more ambitious result, namely that 'the existence of God rather seems to have a probability approximating to 1' (1999, 95; cf. 2007, 110). So much the better for theism, some may happily conclude. But the above observations, if on target, plausibly constitute a reductio of Swinburne's argument. That theism comes out with such a high probability would be too good to be true.

What consequences does all this have for our question about the role of religious experience in Swinburne's probabilistic case for theism? Recall that we are setting the evidence of religious experience aside for the moment, and that Swinburne claims that this evidence can boost the probability of theism further. But as has become apparent by now, for many plausible values of $\mathrm{P}(\mathrm{h} \mid \mathrm{k}), \mathrm{P}(\mathrm{e} \mid \mathrm{h} \& \mathrm{k})$, and $\mathrm{P}(\mathrm{e} \& \sim \mathrm{h} \mid \mathrm{k})$, religious experience cannot in fact fulfil this role. If $\mathrm{P}(\mathrm{h} \mid \mathrm{e} \& \mathrm{k})$ is already as high as it is on these values, religious experience has little if anything left to do. 
How could Swinburne respond? In the above quote from $\mathrm{EG}^{2}$, he concludes that the probability of theism on all the (non-experiential) evidence will not be less than 1/2. However, a few lines later he ventures to suggest that

'in reality all that my conclusion so far amounts to is that it is something like as probable as not that theism is true, on the evidence so far considered' (EG ${ }^{2}, 341$, emphasis C.J.).

In addition to setting $\mathrm{P}(\mathrm{h} \mid \mathrm{e} \& \mathrm{k})$ to 0.5 , Swinburne now assigns a certain value to the likelihood, or what he calls the 'predictive value', of theism on all the non-experiential evidence: 'With $e$ as all the evidence listed so far', he says, ' $k$ as tautological background evidence, and $h$ as the hypothesis of theism, let's say $\mathrm{P}(\mathrm{e} \mid \mathrm{h} \& \mathrm{k})=1 / 3^{\prime}\left(\mathrm{EG}^{2}, 339\right)$. Now, both these assignments are obviously inconsistent with the assignments of $\mathrm{P}(\mathrm{e} \mid \mathrm{h} \& \mathrm{k})=0.01$ and $\mathrm{P}(\mathrm{h} \mid \mathrm{e} \& \mathrm{k}) \gg 0.5$ in table 1 . Instead, examples of plausible values that meet Swinburne's abovementioned constraints include those listed in table 2. In these examples, no convergence-to-1-problem arises.

\begin{tabular}{|l|l|l|l|}
\hline $\mathrm{P}(\mathrm{h} \mid \mathrm{k})$ & $\mathrm{P}(\mathrm{e} \mid \mathrm{h} \& \mathrm{k})$ & $\mathrm{P}(\mathrm{e} \& \sim \mathrm{h} \mid \mathrm{k})$ & $\mathrm{P}(\mathrm{h} \mid \mathrm{e} \& \mathrm{k})$ \\
\hline 0.1 & $0.3333 \ldots$ & $0.0333 \ldots$ & 0.5 \\
\hline 0.01 & $0.3333 \ldots$ & $0.00333 \ldots$ & 0.5 \\
\hline 0.001 & $0.3333 \ldots$ & $0.000333 \ldots$ & 0.5 \\
\hline 0.0001 & $0.3333 \ldots$ & $0.0000333 \ldots$ & 0.5 \\
\hline
\end{tabular}

table 2

However, the problem with this response is that, as far as I can see, Swinburne stipulates these numerical values of $\mathrm{P}(\mathrm{h} \mid \mathrm{e} \& \mathrm{k})$ and $\mathrm{P}(\mathrm{e} \mid \mathrm{h} \& \mathrm{k})$ with little or no independent argument for them. He does put forth considerations of why $\mathrm{P}(\mathrm{h} \mid \mathrm{e} \& \mathrm{k})$, the posterior probability of theism on all the non-experiential evidence, is at least 0.5 . But why this would 'in reality' amount to the conclusion 'that it is something like as probable as not that theism is true' remains unclear. In fact, it is hard to see that anything in Swinburne's core argument, apart from the stipulations just mentioned, would rule out the values listed in rows 2-4 in table 1 . But then it is not clear why only such value assignments as those in table 2 , but not those in table 1 , should be legitimate. 
Another version of the worry is this. If we take Bayesianism seriously, then we should construe Swinburne's cumulative case for theism in terms of Bayesian conditionalization. But here too $\mathrm{P}(\mathrm{h} \mid \mathrm{e} \& \mathrm{k})$ rapidly converges towards 1 if, for example, the initial values are set to $\mathrm{P}(\mathrm{h} \mid \mathrm{k})=0.00001$, and $\mathrm{P}(\mathrm{e} \& \sim \mathrm{h} \mid \mathrm{k})=0.0000001$. The classical or simple principle of conditionalization, often called 'strict conditionalization', says, roughly, that if we acquire new evidence $e$ for a given proposition or hypothesis $h$ - where obtaining such evidence is construed as becoming confident of a proposition stating that $e$ and setting your credence in $e$ to 1 - then we should update on $e$ by altering our probability for $h$ accordingly. ${ }^{8}$ Moreover, the new probability of $h$ thus obtained is its old probability conditional on the previously acquired evidence $e$. In short,

Strict Bayesian Conditionalization: $\mathrm{P}_{\text {new }}(\mathrm{h} \mid \mathrm{k})=\mathrm{P}_{\text {old }}(\mathrm{h} \mid \mathrm{e} \& \mathrm{k})$

As an example of strict conditionalization, consider the values in table 3 (cf. Löffler 1999, 97; 2007, 112).

Once more, we have a rapid convergence towards 1 . I think that, if one takes Swinburne's Bayesianism seriously, one should indeed construe his 'cumulative case for theism' in terms of strict conditionalization. As table 3 shows, however, this can yield the result that after the fifth piece of evidence, no (or almost no) work is left for religious experience; indeed, arguably the case for theism would be more or less completed as early as the third piece of evidence has been considered. Swinburne might respond once more that his

\begin{tabular}{|l|l|l|l|l|}
\hline Given the $\ldots$ & $\mathrm{P}(\mathrm{h} \mid \mathrm{k})$ & $\mathrm{P}(\mathrm{e} \mid \mathrm{h} \& \mathrm{k})$ & $\mathrm{P}(\mathrm{e} \& \sim \mathrm{h} \mid \mathrm{k})$ & $\mathrm{P}(\mathrm{h} \mid \mathrm{e} \& \mathrm{k})$ \\
\hline $1^{\text {st }}$ piece of evidence & 0.00001 & 0.00001 & 0.0000001 & $0.000999 \ldots$ \\
\hline $2^{\text {nd }}$ piece of evidence & $0.000999 \ldots$ & 0.00001 & 0.0000001 & $0.090819 \ldots$ \\
\hline $3^{\text {rd }}$ piece of evidence & $0.090819 \ldots$ & 0.00001 & 0.0000001 & $0.900819 \ldots$ \\
\hline $4^{\text {th }}$ piece of evidence & $0.900819 \ldots$ & 0.00001 & 0.0000001 & $0.989020 \ldots$ \\
\hline $5^{\text {th }}$ piece of evidence & $0.989020 \ldots$ & 0.00001 & 0.0000001 & $0.989990 \ldots$ \\
\hline
\end{tabular}

table 3 


\begin{tabular}{|l|l|l|l|l|}
\hline Given the $\ldots$ & $\mathrm{P}(\mathrm{h} \mid \mathrm{k})$ & $\mathrm{P}(\mathrm{e} \mid \mathrm{h} \& \mathrm{k})$ & $\mathrm{P}(\mathrm{e} \& \sim \mathrm{h} \mid \mathrm{k})$ & $\mathrm{P}(\mathrm{h} \mid \mathrm{e} \& \mathrm{k})$ \\
\hline $1^{\text {st }}$ piece of evidence & 0.01 & 0.33333333 & 0.3 & 0.01098901 \\
\hline $2^{\text {nd }}$ piece of evidence & 0.01098901 & 0.33333333 & 0.3 & 0.01206273 \\
\hline $3^{\text {rd }}$ piece of evidence & 0.01206273 & 0.33333333 & 0.3 & 0.01322576 \\
\hline $4^{\text {th }}$ piece of evidence & 0.01322576 & 0.33333333 & 0.3 & 0.01448247 \\
\hline $5^{\text {th }}$ piece of evidence & 0.01448247 & 0.33333333 & 0.3 & 0.01583679 \\
\hline
\end{tabular}

table 4

0.5-constraint rules out values of $\mathrm{P}(\mathrm{e} \mid \mathrm{h} \& \mathrm{k})$ that are too close to 1 and that he therefore need not accept the probability assignments in table 3. But once more the challenge for him is to provide independent arguments to the effect that his constraints $-\mathrm{P}(\mathrm{e} \& \sim \mathrm{h} \mid \mathrm{k}) \cong 1 / 3$ and $\mathrm{P}(\mathrm{h} \mid \mathrm{e} \& \mathrm{k}) \cong 0.5$ - are not just arbitrarily chosen to avoid implausible results.

For the record, note finally that some probability assignments will of course have a different effect (see table 4). If nothing but the evidence from religious experience were left to be added here, then the probabilistic prospects for theism would not look rosy. In these examples, thousands of additional pieces of evidence would be needed to reach a probability of 0.5. However, the probability assignments in table 4 are not compatible with Swinburne's claims that $\mathrm{P}(\mathrm{e} \& \sim \mathrm{h} \mid \mathrm{k})$ is very low and that it is much lower than $\mathrm{P}(\mathrm{h} \mid \mathrm{k})$. If we accept these constraints, examples such as those in table 4 are ruled out.

\section{Can Evidence From Religious Experience Justify Religious Belief?}

My second observation is inspired by a recent debate about a Bayesian objection to dogmatism or, more broadly, to phenomenal conservatism about the justificatory potential of perceptual seemings. Dogmatism (so-called by James Pryor and others) is the view that perceptual seemings can provide 'immediate' but defeasible epistemic justification for the corresponding perceptual beliefs, where the justification of a belief is immediate if and only if it does not depend (even in part) on the subject's having antecedent justification for ruling out possible defeaters. However, the Bayesian objector observes, justification is closed under known entailment; that is:

(Justification Closure) Necessarily: If $S$ is epistemically justified in believing that $p$, and knows that $p$ entails $q$, then $S$ is epistemically justified in believing that $q$. 
Hence, the objector continues, if a perceptual seeming provides immediate experiential justification for believing that $p$, then it should, at least in typical cases (where $\mathrm{S}$ knows that $p$ entails $q$ ), also yield justification for disbelieving sceptical alternatives to $p$. But it doesn't - at least not if gaining justification for a proposition corresponds to raising one's rational credence in it. For example, if Moore's perceptual experience justifies him in believing that he has hands, it should also justify him in believing that he is not deceived by an evil demon; that he is not a handless brain in a vat having experiences as of hands; that he doesn't have fake hands; and so forth. However, the objection shows that, given certain views about justification and rational confidence, the truth is that having, and becoming reflectively aware of, certain perceptual seemings cannot by themselves justify believing that such sceptical alternatives are false. Swinburne's argument from religious experience, I submit, has an analogous structure to the dogmatist's argument about the epistemic role of ordinary perceptual seemings. Both arguments are based on the view that seemings can provide some kind of basic, immediate justification for the corresponding beliefs. But this means that Swinburne's argument is also vulnerable to the Bayesian objection, especially since Swinburne explicitly accepts Bayesian confirmation theory. ${ }^{9}$

Perhaps the most influential version of the Bayesian argument against dogmatism is Roger White's (2006), which goes roughly as follows. ${ }^{10}$ Suppose $e$ is the evidence that you are having an experience as of having hands; $h$ is the hypothesis that you have hands; and FAKE is the hypothesis that you have fake hands that look exactly like real hands. $e$, the argument goes, raises the probability of, or confirms, not only $h$, but also FAKE. (In the locutions current these days, we could say that $e$ relays FAKE news....) This means that $\mathrm{P}($ FAKE $\mid \mathrm{e})>\mathrm{P}($ FAKE $)$. However, from this it follows that $\mathrm{P}(\mathrm{h} \mid \mathrm{e})<\mathrm{P}(\sim \mathrm{FAKE})$. That is, your new probability for the proposition that you have hands, updated on the fact that you have an experience as of having hands, cannot exceed your old probability for the proposition that you do not have fake hands.

We may postpone the formal details for a moment, since I am about to discuss a proof for a structurally similar result concerning religious experience. What is important for now is that the Bayesian argument against phenomenal conservatism also yields certain conclusions about confidence and justification. White maintains that if I gain justification for a hypothesis, then my confidence in its truth should increase' (2006, 531). By Justification Closure it appears to follow that, if by having evidence from perceptual experience I acquire justification for some perceptual belief that $p$, then, if I know that $p$ entails the falsehood of 
certain sceptical hypotheses incompatible with $p$, I acquire justification for disbelieving these sceptical hypotheses. What the Bayesian argument shows, however, is that experience cannot deliver such justification by itself. It shows that, for example, having a perceptual experience as of hands does not improve your antecedent justification for believing that you are not in the FAKE situation. You cannot gain justification for ruling out such situations simply by having a perceptual experience. ${ }^{11}$

Swinburne is not very fond of discussing scepticism. ${ }^{12}$ (Perhaps this is a context in which I may interject another anecdote: When I once asked Swinburne what he thought about epistemology fuelled by the attempt to solve sceptical puzzles, his reply was: 'Scepticism is rather boring, isn't it?') However, maybe we can learn something from engaging with sceptical puzzles. ${ }^{13}$ Indeed, in the present case we can adapt the Bayesian argument against phenomenal conservatism to Swinburne's views about the role of religious experience. Before doing this, two more preliminary remarks are in order.

First, I have already mentioned the idea of 'becoming reflectively aware of experiences'. The reason for this specification is that the Bayesian argument works with evidence construed in terms of propositions and must therefore assume that the agent knows that she is having the experience. The dogmatist, by contrast, typically maintains that, other things being equal, $S$ 's simply having perceptual experiences justifies $S$ in holding the corresponding beliefs. Along with most participants in the discussion I do not think that this discrepancy is problematic. When he delivered his proof of an external world, Moore was reflectively aware of his experience as of hands, and we may limit the discussion to such cases.

Second, as outlined above, Swinburne's treatment of religious experience proceeds in two steps. One, which draws on his Principle of Credulity, is concerned with the 'first-personperspective' of those who have religious experiences. Another, which draws on his Principle of Testimony, takes a third-person perspective, available also to those who lack such experiences. It will be convenient to present the argument from a first-person perspective, so I will envisage an agent who accepts Swinburne's argument from non-experiential evidence and then considers his or her religious experiences. However, I believe that my observations carry over to the third-person case as well.

Suppose, then, that you have a religious experience apparently of God. As before, let us concede that there is nothing generally problematic with this assumption. (For example, let us set aside worries to the effect that no experience can have this sort of metaphysically ambitious content.) $h$ is Swinburne's hypothesis of theism; $e$ the agent's evidence that she has 
or has had an experience as of God. For ease of exposition, let us leave aside tautological background knowledge $k$. Now, let $h^{*}$ be an alternative hypothesis from the list of the three options Swinburne suggests ((i) many gods; (ii) no God or gods, but a physical universe that brings about all current states and events; (iii) no explanation at all; see EG2, 339-340). For example, let us identify $h^{*}$ with option (ii). I will refer to this hypothesis as a "purely naturalistic explanation' of the universe and of everything that happens therein, including religious experience. Finally, $h$ entails $\sim h^{*}$. Adopting Swinburne's Bayesian apparatus, and applying strict conditionalization, we can then reason as follows.

First, we observe that, although $e$ is evidence for (or confirms) $h$, it is also evidence for (or confirms) $h^{*}$, since ex hypothesi $h^{*}$ explains $e ; \mathrm{P}\left(\mathrm{h}^{*} \mid \mathrm{e}\right)>\mathrm{P}\left(\mathrm{h}^{*}\right) .{ }^{14}$ This gives us proposition (1) below. For if $e$ confirms $h^{*}$, it disconfirms $\sim h^{*}{ }^{15}$ Moreover, according to strict conditionalization you should, upon becoming aware of $e$, update your credence in $e$ to 1 and adjust your probability accordingly (step 2). Hence:

(1) $\mathrm{P}_{\text {old }}\left(\sim \mathrm{h}^{*} \mid \mathrm{e}\right)<\mathrm{P}_{\text {old }}\left(\sim \mathrm{h}^{*}\right)$

| premise (from assumptions, probability calculus)

(2) $\mathrm{P}_{\text {new }}\left(\sim \mathrm{h}^{*}\right)=\mathrm{P}_{\text {old }}\left(\sim \mathrm{h}^{*} \mid \mathrm{e}\right)$

| strict conditionalization

(3) $\mathrm{P}_{\text {new }}\left(\sim \mathrm{h}^{*}\right)<\mathrm{P}_{\text {old }}\left(\sim \mathrm{h}^{*}\right)$

| 1,2

(4) $\mathrm{P}_{\text {new }}(\mathrm{h}) \leq \mathrm{P}_{\text {new }}\left(\sim \mathrm{h}^{*}\right)$

| since $h$ entails $\sim h^{*}$; probability calculus

(5) $\mathrm{P}_{\text {new }}(\mathrm{h})<\mathrm{P}_{\text {old }}\left(\sim \mathrm{h}^{*}\right)$

|3, 4

(5) says that the new probability of theism, i. e., its probability updated on the evidence of religious experience, $e$, does not exceed the prior probability of $\sim h^{*}$. This latter, old probability that the alternative naturalistic hypothesis is false sets an upper limit for $\mathrm{P}_{\text {new }}(\mathrm{h})$.

Now, consider what this conclusion means in terms of justification. According to Swinburne's internalist theory of epistemic justification, as he forcefully lays it out in his book Epistemic Justification, a belief is justified or epistemically adequate if and only if its grounds render it more probable than not:

'For an internalist ... the adequacy of grounds is a matter of inductive probability. A belief is justified in so far as its grounds render it inductively probable that the proposition believed is true (that is, give it a probability greater than 1/2)' $(1999,72)$.

Applied to Swinburne's case for theism, this means that an agent is justified (or epistemically rational) in believing that God exists only if his grounds give that proposition a probability 
that exceeds 0.5. So let us plug in Swinburne's claim that the evidence from religious experience raises the probability of theism beyond the 0.5 -threshold:

$\begin{array}{ll}\text { (6) } \mathrm{P}_{\text {new }}(\mathrm{h})>0.5 & \mid \text { premise } \\ \text { (7) } 0.5<\mathrm{P}_{\text {new }}(\mathrm{h})<\mathrm{P}_{\text {old }}\left(\sim \mathrm{h}^{*}\right) & \mid 5,6 \\ \text { (8) } \mathrm{P}_{\text {old }}\left(\sim \mathrm{h}^{*}\right)>0.5 & \mid 7\end{array}$

Given the conceptual link between epistemic justification and inductive probability, what this conclusion tells us is that, in order to be epistemically justified in believing $h$ after considering religious experience, you must already be justified in believing that the naturalistic alternative to theism, $h^{*}$, is false. In other words, contrary to what may appear to be a natural view, religious experience does not give you any additional justification for believing that this alternative hypothesis is false. This conclusion can clearly be generalized to other alternative hypotheses.

There is another interesting aspect. In $\mathrm{EG}^{1}$ Swinburne summarizes his argument as follows:

'My conclusion so far then has been that the probability of theism is none too close to 1 or 0 on the evidence so far considered. However, so far in this chapter I have ignored one crucial piece of evidence, the evidence from religious experience. ... I concluded the last chapter (p. 274) with the claim that, unless the probability of theism on other evidence is very low indeed, the testimony of many witnesses to experiences apparently of God suffices to make many of those experiences probably veridical. That is, the evidence of religious experience is in that case sufficient to make theism over all probable. ... I believe that I have shown in this chapter [Chapter 14] that that condition is well satisfied' (EG $\left.{ }^{1}, 290-291\right)$.

I have granted that Swinburne's C-inductive arguments in the first part of the book show that the probability of theism is not too low. Of course, this locution is imprecise. But it is natural to maintain that, for example, a probability for $h$ of 0.3 or of 0.4 will meet this constraint. (For present purposes we may technically assume any threshold up to, but not including, 0.5.) If the probability of $h$ before considering religious experience is 0.3 , the probabilities of all the competing hypotheses which could explain the occurrence of religious experiences sum to 0.7. So $\mathrm{P}\left(\mathrm{h}^{*}\right)$ could be $>0.5$, and thus $\mathrm{P}\left(\sim \mathrm{h}^{*}\right)<0.5$. But if $\mathrm{P}\left(\sim \mathrm{h}^{*}\right)$ does not exceed 0.5 , then, 
as I have shown, the new probability for $h$, i. e., its probability on the evidence of religious experience, cannot exceed 0.5 either. This is what propositions (5)-(8) bring out. And if this probability, or rational credence, doesn't exceed the 0.5-threshold, then, according to Swinburne, it doesn't justify the 'positive belief' that $h$ rather than one of its rivals is true.

This shows that it is indeed much safer for Swinburne to hold that the probability of theism on all the non-experiential evidence is at least 0.5 . $\mathrm{P}\left(\mathrm{h}^{*}\right)$ must then be smaller than 0.5 and hence $\mathrm{P}\left(\sim \mathrm{h}^{*}\right)$ greater than 0.5 , provided that the other alternatives have non-zero probability (which Swinburne assumes). As we have seen, in $\mathrm{EG}^{2}$ he concludes that the probability in question is 0.5 . This is consistent with the result in (8). But this move has the cost of weakening Swinburne's argument regarding the result of his C-inductive arguments. For it is much harder for him to maintain that the latter deliver exactly (or 'more or less exactly') this value. Many philosophers, friends and foes of theism alike, might grant him the intermediate conclusion from $\mathrm{EG}^{1}$ that the non-experiential arguments establish a probability for theism that is 'well away from 1 or 0 ', yet reject the claim in $\mathrm{EG}^{2}$ that this probability is 0.5 .

\section{Conclusion: The Probability of Theism and the Rationality of Faith}

Various defences of dogmatism (or phenomenal conservatism) have been suggested in response to the Bayesian objection. None is uncontroversial, and each has its costs. For example, some accept the alleged inconsistency between dogmatism and classical Bayesianism but suggest revising the latter. (For some options see Pryor (2013).) Weatherson (2007) suggests substituting classical conditionalization with a 'Keynesian model' of learning. Kung (2010) proposes revising the standard Bayesian notion of confirmation so that a piece of evidence $e$ can confirm $h$ even if $\mathrm{P}(\mathrm{h} \mid \mathrm{e}) \leq \mathrm{P}(\mathrm{h})$. Others argue that on closer inspection the alleged inconsistency between dogmatism and Bayesianism is doubtful, because the conceptual relations between conditional probabilities and updating, on the one hand, and rational confidence and justification, on the other, are not as straightforward as the Bayesian objector assumes (see, e. g., Silins (2007)). But given Swinburne's overall theory of inductive reasoning and epistemic justification, it seems to me that none of these options would be particularly attractive to him.

However, I wish to suggest another response. It is of the bite-the-bullet type as regards the problems discussed in this article, but proposes a zoom-out to the broader picture alluded to in the first sentences of the introduction. The central task for the philosophy of religion - 
and no one has convinced me of this more thoroughly than Richard Swinburne - is to explore the nature and rationality of faith. But faith, as Swinburne himself argues at length in one of his other modern philosophy-of-religion classics, Faith and Reason, is a richer attitude than belief: fides does not reduce to doxa. Faith includes trust, hope, affect, ritual, commitments to a certain way of life, and much more. Faith is a form of Weltanschauung (roughly: 'worldview'). All this, as I have said, is salient in Swinburne's work, and he certainly has much to teach me about the details of the picture. Yet, if we take this view seriously, I should like to dispute his claim in The Existence of God that the crucial question is whether we can develop a good P-inductive argument for theism - that is, whether we have an argument that it is more probable than not that God exists.

In fact, it seems to me, in order to argue for the rationality of faith it would amply suffice to accept as overall conclusion the conclusion that Swinburne draws, in the first edition of The Existence of God, before he considered religious experience: that the probability of theism is 'not too low', while this locution should be allowed to refer to values below the 0.5-threshold. What a reasonable threshold will be is a matter for discussion. And many will dispute (typically in light of problems of evil) that even such a claim can be rationally supported. But if it can, a crucial necessary condition for rational faith is fulfilled. In Faith and Reason Swinburne himself provides the tools for precisely this conclusion. There he explicitly argues that, for example, rational Christian faith is compatible with what he calls 'weak belief' that the Christian creeds are true. 'Although normally the sole alternative to a belief that $p$ is its negation', he notes, 'sometimes there will be other alternatives. This will be the case where $p$ is one of a number of alternatives being considered in a certain context. In that case to believe that $p$ will be to believe that $p$ is more probable than any one of these alternatives (but not necessarily more probable than the disjunction of the alternatives)' (2005, 6). In Swinburne's example a speaker may correctly assert that he believes that Liverpool will win the cup, given that he believes this to be more probable than that Leeds will win the cup, that Manchester will win the cup, and so forth, even if he does not think it is more probable than not that Liverpool will win. This kind of belief, weak belief, does not require that the agent's epistemic probability of $p$ exceed 0.5 . Swinburne then argues that such weak belief suffices for rational religious belief, or rational faith:

'[A]ll that is needed in respect of belief in a creed is belief that it is more probable that that creed is true than that any rival creed is true, a rival creed being one that justifies the pursuit of a different religious way' (Swinburne 2005, 162). 
In other words, if there is more than one logical alternative, religious belief can be rational even if it does not take the creed under consideration to be more probable than not. ${ }^{16}$ I suggest applying this insight to the relation between the probability of theism and the rationality of faith. The occurrence of religious experience may still be an important piece of evidence. But it doesn't have to raise the conditional probability of theism beyond the 0.5 -threshold. Given the complex nature of faith, weak rational belief in theism can be strong enough for rational faith. ${ }^{17}$

\section{Literature}

BROGARD, B. (2013) 'Phenomenal Seemings and Sensible Dogmatism', in Tucker (2013a), 270-289.

CHUDNOFF, E. (2014) Review of Tucker 2013a, Notre Dame Philosophical Reviews 2014.05.04.

COHEN, St. (2005) 'Why Basic Knowledge is Easy Knowledge', Philosophy and Phenomenological Research, 70, 417-430.

CRUPI, V. (2015) 'Confirmation', in Edward N. Zalta (ed.) The Stanford Encyclopedia of Philosophy (Winter 2016 Edition), = <https://plato.stanford.edu/archives/win2016/entries/confirmation/>.

FORGIE, J. W. (1986) 'The Evidential Value of Religious Experience', International Journal for Philosophy of Religion, 19, 145-159.

GALE, R. (1994) 'Swinburne's Argument from Religious Experience', in A. Padgett (ed.) Reason and the Christian Religion (Oxford: Oxford University Press), 39-63.

GUTENSON, C. E. (1997) 'What Swinburne Should Have Concluded', Religious Studies, 33, 243-247.

HAWTHORNE, J. (2004) Knowledge and Lotteries (Oxford: Oxford University Press).

HUEMER, M. (2001): Skepticism and the Veil of Perception (Lanham: Rowman \& Littlefield).

KUNG, P. (2010) 'On Having No Reason: Dogmatism and Bayesian Confirmation', Synthese, 177, 1-17.

LÖFFLER, W. (1999) 'An Overlooked Consequence of Swinburne's Probabilistic Theology', Disputatio Philosophica, 1, 90-100. 
LÖFFLER, W. (2007) ,Gott als beste Erklärung der Welt: Richard Swinburnes probabilistischer Gottesbeweis', in R. Langthaler and W. Treitler (eds) Die Gottesfrage in der europäischen Philosophie und Literatur des 20. Jahrhunderts (Vienna et al.: Böhlau), 99-117.

MAITZEN, St. (1991) 'Swinburne on Credal Belief', International Journal for Philosophy of Religion, 29, 143-157.

MARTIN, M. (1986) 'The Principle of Credulity and Religious Experience', Religious Studies, 22, 79-93.

MICHON, C. (2017) 'Believing God - An Account of Faith as Personal Trust', Religious Studies, this issue.

MILlER, B. T. (2016) 'How to Be a Bayesian Dogmatist', Australasian Journal of Philosophy, 94, 766-780.

MORETTI, L. (2015a) 'In Defence of Dogmatism', Philosophical Studies, 172, 261-282.

MORETTI, L. (2015b) 'Phenomenal Conservatism', Analysis, 75, 296-309.

NETA, R. (2010) 'Liberalism and Conservatism in the Epistemology of Perceptual Belief', Australasian Journal of Philosophy, 88, 685-705.

PRYOR, J. (2000) 'The Sceptic and the Dogmatist', Nous, 34, 517-549.

PRYOR, J. (2013) 'Problems for Credulism', in Tucker (2013a), 89-131.

SCHIFFER, ST. (2004: 'Scepticism and the Vagaries of Justified Belief', Philosophical Studies, 119, 161-184.

SILINS, N. (2007) 'Basic Justification and the Moorean Response to the Skeptic', in T. Szabo Gendler and J. Hawthorne (eds) Oxford Studies in Epistemology, 2 (Oxford: Oxford University Press), 108-142.

SWINBURNE, R. (1973) An Introduction to Confirmation Theory (London: Methuen \& Co LTD).

SWINBURNE, R. (1979=EG ${ }^{1}$ ) The Existence of God, first edition (Oxford: Oxford University Press).

SWINBURNE, R. (1999) Epistemic Justification (Oxford: Oxford University Press).

SWINBURNE, R. (2004=EG $\left.{ }^{2}\right)$ The Existence of God, second edition (Oxford: Oxford University Press).

SWINBURNE, R. (2005) Faith and Reason (Oxford: Oxford University Press), first edition 1981.

SWINBURNE, R. (typescript) 'Phenomenal Conservatism and Religious Experience', forthcoming. 
TUCKER, C. (2013a) (ed.) Seemings and Justification: New Essays on Dogmatism and Phenomenal Conservatism (Oxford: Oxford University Press).

(2013b) 'Seemings and Justification: An Introduction', in Tucker (2013a), 1-29.

WHITE, R. (2006) 'Problems for Dogmatism', Philosophical Studies, 131, 525-557.

WEATHERSON, B. (2007) 'The Bayesian and the Dogmatist', Proceedings of the Aristotelian Society CVII, part 2, 169-185.

${ }^{1}$ Of course, this does not imply that I agree with all or even most of Swinburne's positions.

${ }^{2}$ Moretti (2015a), 261; in its contemporary sense the label originates with Pryor (2000).

${ }^{3}$ Is the cumulative force of the various pieces of evidence an additional piece of evidence? I think that Swinburne would want to claim this, but for present purposes we don't need to settle this question.

${ }^{4}$ This is the way Chudnoff (2014) slices the cake. Tucker (2013b, 2) defines phenomenal conservatism as the view that, 'if it seems to $S$ that $P$, then in the absence of defeaters, $S$ thereby has justification for believing $P$ '.

${ }^{5} \mathrm{P}(\mathrm{h} \mid \mathrm{e} \& \mathrm{k})=\frac{(\mathrm{P}(\mathrm{e} \mid \mathrm{h} \& \mathrm{k}) \mathrm{P}(\mathrm{h} \mid \mathrm{k})}{\mathrm{P}(\mathrm{e} \mid \mathrm{k})}$

${ }^{6}$ For a proof see Löffler (1999), 93.

${ }^{7}$ The equivalent formulation in $\mathrm{EG}^{2}, 339$, is: $\mathrm{P}(\mathrm{h} \mid \mathrm{e} \& \mathrm{k})=\frac{(\mathrm{P}(\mathrm{h} \mid \mathrm{k}) \mathrm{P}(\mathrm{e} \mid \mathrm{h} \& \mathrm{k})}{(\mathrm{P}(\mathrm{h} \mid \mathrm{k}) \mathrm{P}(\mathrm{e} \mid \mathrm{h} \& \mathrm{k})+\mathrm{P}(\mathrm{e} \mid \sim \mathrm{h} \& \mathrm{k}) \mathrm{P}(\sim \mathrm{h} \mid \mathrm{k})}$

${ }^{8}$ The alternative is so-called 'Jeffrey Conditionalization' which does not require setting the credence of $e$ on which you update to 1. Swinburne's discussions suggest that he accepts simple or strict conditionalization.

${ }^{9}$ Perhaps his account is somewhat non-standard in that it opts for an objectivist interpretation of the relevant probabilities. Fortunately this question, which leads into complex issues about the metaphysics of probability, is not immediately relevant to the present argument.

${ }^{10}$ For similar summaries see, e. g., Miller (2016), 770-771; or Pryor (2013), 111.

${ }^{11}$ In addition to White's argument, versions of this case have been pressed by Cohen (2005), Hawthorne (2004), 73-76; Schiffer (2004). For helpful extended discussions see also Weatherson (2007), Neta (2010), Kung (2010), Pryor (2013), Tucker (2013b), Moretti (2015a, 2015b), and Miller (2016). My adaptation below concerning Swinburne's argument follows, in steps 1-5, Pryor's and Miller's reconstruction of White's argument.

${ }^{12}$ See, e. g., his Epistemic Justification. Contrary to many other internalists about epistemic justification, Swinburne does not develop his theory from a discussion of sceptical problems; he deals with scepticism only in an appendix.

13 It was only after the final version of this paper was completed that I noticed that Swinburne has an article forthcoming on phenomenal conservatism ('Phenomenal Conservatism and Religious Experience'), based on a talk he gave in June 2015 in Oxford. In this article, Swinburne deepens his discussion of the principle of credulity and relates it to more recent work on phenomenal conservatism. He does not directly discuss White's Bayesian argument against phenomenal conservatism, but Swinburne argues that, "of course on any psychological evidence that humans want to believe that there is a God, the [intrinsic] probability [that a given person will have an apparent awareness of the presence of God] might be significant. But again in assessing intrinsic probability I am assuming the absence of such defeaters" (typescript, 20). Note that my argument does not assume that such psychological evidence is significant. Rather, it claims merely that the probability of certain naturalistic hypotheses which include such psychological claims is not close to zero, and that such hypotheses can serve as rival explanations for the occurrence of religious experience. 
${ }^{14}$ Of course, if there were only two competing hypotheses $h_{1}$ and $h_{2}$, then, since their priors sum to $1, e$ could not confirm (and thus raise the probability of) both of them. However, in the present case we have more than two competing alternatives.

${ }^{15}$ But $e$ confirms $h$, and $h$ entails $\sim h^{*}$, which is disconfirmed by $e$. Can a given piece of evidence confirm some hypothesis $h$ and at the same time disconfirm another hypothesis that is entailed by $h$ ? Yes. Suppose we realize that some antibiotic treatment does not cure a given infection (let this be our evidence $e$ ). Arguably, $e$ confirms any number of mutually incompatible viral diagnoses. Suppose there are two such alternative diagnoses $V_{1}$ and $V_{2}$, where $V_{1}$ entails $\sim V_{2}$ and $V_{2}$ entails $\sim V 1$. $e$ confirms both $V_{1}$ and $V_{2}$. This example is borrowed from Crupi (2015). Swinburne himself discusses similar cases in his Introduction to Confirmation Theory, 57-58.

${ }^{16}$ For further discussion of Swinburne's views on this issue see, e. g., Maitzen (1991) and Michon (2017).

${ }^{17}$ Parts of this paper have been presented at a conference in honor of Richard Swinburne at the occasion of his 80es birthday, September 2015 at Oriel College, Oxford. For helpful comments or discussions I am grateful to the audience and especially to Katherine Dormandy, Winfried Löffler, Nicholas Shackel, and Christian Tapp. 